\title{
From Palermo to the Streets of Oslo: Pros and cons of the trafficking framework
}

\author{
Synnøve Økland Jahnsen and May-Len Skilbrei
}

Please cite this article as: S $\varnothing$ Jahnsen \& M-L Skilbrei, 'From Palermo to the Streets of Oslo: Pros and cons of the trafficking framework', Anti-Trafficking Review, issue 4, 2015, pp. 156-160, www.antitraffickingreview.org

The development of Norwegian anti-trafficking efforts and how they relate to obligations set forth by the United Nations Trafficking Protocol (also known as the 'Palermo Protocol') illustrates some of the constraints connected to international policymaking. While national trafficking policies on paper are in alignment with the definitions and priorities in the Protocol, the local and institutional context simultaneously influence how these international ambitions are interpreted and implemented. Thus, we argue that to understand the impact of the Protocol one must necessarily explore how it interacts with national agendas and instruments.

Local realities have been, and always will be, imbedded in distinct spatial, cultural and historical discourses. When Norway signed the Trafficking Protocol in the year 2000, Norwegian prostitution and labour market relations were not as marked by transnational mobility as they would be only a few years later. In the first period after its implementation, Norwegian authorities invested a lot of political prestige in developing policies in alignment with the priorities of the Protocol. Later, as knowledge and experience was gained, these policies had to be adjusted significantly as the 'map turned out not to fit the terrain'. ${ }^{1}$

We want to highlight two distinct features of the implementation of the Protocol in the Norwegian context. The first is how its definitions and instruments interact with the already established abolitionist agenda on prostitution. The second is how efforts against forced labour have been under-prioritised.

Since ratifying the Protocol in 2003, the Norwegian government has altered the Penal Code and produced four plans of action. This can be seen as an expression of Norwegian authorities' eagerness to adhere to the standards of the Protocol. At the same time it can be understood as a correspondence between the trafficking agenda and changing local definitions of prostitution. Public debates concerning prostitution policy have taken place since the early 1980s. A reoccurring theme has been whether or not to criminalise the purchase of sex.

At the beginning, taking a political stand in support of the Sex Purchase Act, which criminalises the purchase of sex, was a fairly marginalised position mainly promoted by the anti-pornography movement. The arguments that supported the ban were primarily based on feminist arguments that equated prostitution with violence against women and viewed it as a societal problem that is both damaging to the individuals involved and to

M-L Skilbrei, 'Moving Beyond Assumptions? The Framing of Anti-trafficking Efforts in Norway’ in Ragnhild Sollund (ed.), Transnational Migration, Gender and Rights, Emerald Insight Publishing, 2012.

This is an open-access article distributed under the terms of the Creative Commons Attribution License (CC-BY). Under CC-BY license, the public is free to share, adapt, and make commercial use of the work. Users must always give proper attribution to the author(s) and the AntiTrafficking Review. 
the society at large. ${ }^{2}$ With emerging concerns over migration to Norway during the $1990 \mathrm{~s}$ and the implementation of the Trafficking Protocol, debates over prostitution and trafficking increasingly became conflated. Thus, when the debate on the Sex Purchase Act resurfaced in the public debate in 2006, the terms 'trafficking' and 'prostitution' were used interchangeably. There is undoubtedly much that can be said regarding this particular feature of the Norwegian prostitution policy. ${ }^{3}$ What we want to underline here is that the Sex Purchase Act only gained political momentum when the anti-prostitution agenda corresponded with increasing fears over unwanted migration and organised crime, and that such a law was implemented in 2009.

The introduction of the Sex Purchase Act is not the only change in legislation that can be linked to the Protocol. The introduction of a Trafficking Act in the Penal Code also resulted in revisions of the Procurement Act, which criminalises aiding and abetting prostitution. Most importantly, any form of prostitution or organisation of someone else's prostitution is now criminalised in Norway, something that was not the case pre-Palermo. The application, and, not least the combination, of the Trafficking Act, the Sex Purchase Act and the Procurement Act has led to an increased policing of prostitution. ${ }^{4}$

The shift towards a penal approach to prostitution needs to be seen together with how efforts to assist victims of trafficking have led to the establishment of a broad range of services that aim to motivate them to exit prostitution. The main bulk of these services are provided by non-governmental organisations (NGOs) and municipal institutions that were originally set up to assist women in prostitution or women who had experienced violence. Organising services in this way has led to a bias in how they are designed, who they are targeted at, and who receives them. Services and identification of victims of trafficking are predominantly directed at migrant women in prostitution, not men or victims of other forms of exploitation.

To understand the way international ambitions are translated into national and local policy it is important to look at how trafficking as a label for societal problems has offered funding opportunities and increased visibility and importance for some political issues, while others are neglected. While the NGOs and governmental bodies working on prostitution and gender issues before 2003 readily appropriated the trafficking concept, although often for pragmatic reasons, NGOs and governmental bodies working on labour and industrial relations have not.

The bias towards prostitution-related trafficking and female victims mirrors the signals of the Trafficking Protocol, as it too prioritises exploitation of women and children. However it also relates to the widespread view in Norway that exploitation in the labour market needs to be approached differently to exploitation in the prostitution market. Neither Norwegian labour unions nor the government seem to have seen the trafficking framework as ideal for addressing discrimination of migrant workers and exploitation in the labour market. This is because the Norwegian labour market is already seen as subject to sophisticated forms of preventive mechanisms seeking to control and regulate, rather than prosecute and penalise. ${ }^{5}$ To approach forced labour as trafficking also mandates changes in the design of Norwegian anti-trafficking work, as this is explicitly designed to address victimisation through sexual exploitation rather than through different forms of labour.

M-L Skilbrei \& C Holmström, Prostitution Policies in the Nordic Region: Ambiguous Sympathies, Farnham, Ashgate, 2013. M-L Skilbrei, 'A Marriage of Convenience between Pragmatism and Principles: The development of Norwegian prostitution policies', Sexuality Research and Social Policy (9)2, 2012, pp. 244-257; S Ø Jahnsen, 'Norge er ikke en Øy (Norway is not an Island): Mediedekningen av kriminaliseringsdebatten i Norge' in M-L Skilbrei \& C Holmström (eds.), Prostitusjon i Norden, Nordiska ministerrådet, Copenhagen, 2008, pp. 255-277.

4 S $\varnothing$ Jahnsen, 'Innestengt eller Utestengt? Norsk prostitusjonspolitikk og kampen mot menneskehandel', PhD thesis, Sosiologisk Institutt, Universitet i Bergen, 2014.

S $\varnothing$ Jahnsen, Menneskehandel og Tvangsarbeid. En forstudie om gråsoneproblematikk innenfor innsatsområdet arbeidsmarkedskriminalitet, PHS Forskning, Oslo, 2014. 
To conclude, it can be considered a positive development that the Trafficking Protocol forced the Norwegian government to take exploitation in cross-border prostitution more seriously than before. Especially important is the establishment of residence permits for victims of trafficking, which are particularly important to victims. ${ }^{6}$ At the same time, the increased policing of prostitution has resulted in a new type of regime where migrants in prostitution are subjected to extensive forms of surveillance and control in the name of rescue and security. ${ }^{7}$ That new policies in practice may increase vulnerabilities to trafficking and other exploitative situations, rather than reduce them, is an issue that is increasingly taken up in discussions in Norway, and in particular as these debates relate to the Sex Purchase Act. ${ }^{8}$ These debates illustrate the unanswered question of how the Trafficking Protocol should ideally be interpreted and implemented bearing in mind national agendas and instruments.

Synnøve Økland Jahnsen works in Norway at the Department of Criminology and Sociology of Law at the University of Oslo, and is affiliated with the Norwegian Police University College and Centre for Women and Gender Research at the University of Bergen. Her areas of expertise are gender, mobility and labour. Her work addresses how 'migration' and 'trafficking' become the locus for contemporary forms of policing and control. Jahnsen is a co-editor of the forthcoming book Assessing European Prostitution Policy. She is also a member of the COST Action Comparing European Prostitution Policies: Understanding Scales and Cultures of Governance (ProsPol).

May-Len Skilbrei is a Professor of Criminology at the University of Oslo. Her research focuses on human trafficking, prostitution, migration, gender and globalisation, and she recently published a book with Ashgate together with Charlotta Holmström on Nordic prostitution policies. She is currently the editor of the Routledge book series Interdisciplinary Studies in Sex for Sale, heads a Working Group of the European Society of Criminology on Immigration, Crime and Citizenship, and is deputy chair of the COST Action Comparing European Prostitution Policies: Understanding Scales and Cultures of Governance (ProsPol).

M-L Skilbrei \& M Tveit, 'Mission Impossible? Voluntarily and dignified repatriation of victims of trafficking to Nigeria' in T-D Truong \& D Gasper (eds.), Transnational Migration and Human Security, Springer Publications, 2008.

$S \varnothing$ Jahnsen, 'Innestengt eller Utestengt?’

I Rasmussen, S Strøm, S Sverdrup \& V W Hansen, 'Evaluering av Forbudet mot Kjøp av Seksuelle Tjenester', Vista Analyse, Oslo, 2014; A Brunovskis \& M-L Skilbrei, 'The Evaluation of the Sex Purchase Act Brings Us No Closer to a Conclusion', Fafo, 2014, retrieved 11 February 2015, http://www.fafoarkiv.no/prostitution/140816-ABR-oped.html 